\title{
The innovation trajectory of eco-cement in the Netherlands: a co-evolution analysis
}

\author{
René Kemp $^{1}$ - Eva Barteková ${ }^{2} \cdot$ Serdar Türkeli $^{1}$
}

Published online: 27 June 2017

(C) The Author(s) 2017. This article is an open access publication

\begin{abstract}
In this article, we scrutinize the innovation trajectory of eco-cement in the Netherlands by examining the innovation nexus of eco-cement manufacturers, scientists/researchers, waste producers and policymakers as part of a broader analysis of markets, policy and society, with special attention to standards and regulations. The influence of policy and innovation interactions are substantiated by policy documents, media news, patterns of eco-cement use, and in-depth interviews conducted with relevant eco-cement actors. Our analysis brings forward empirical evidence of how policymakers are involved in the innovation trajectory of eco-cement in multiple ways through building regulations, sector policies, waste policies, and science and innovation policies. Political economy aspects of regulation and innovation in cement industry (e.g. the cooperative approach of waste authorities with regard to re-use of waste, absence of policies to put a price on $\mathrm{CO}_{2}$ emissions from cement production) are being described, together with the specificities of the cement market. Bans on the disposal of fly ash and sewage sludge resulted in the use of those materials either as a supplementary cementitious material or a fuel. Demand for green cement from is presently growing but meets with several obstacles. Carbon policies are shown to constitute a weak influence. Innovation in eco-cement co-evolved with policy, through mutual dependencies, as a theoretical finding for innovation studies.
\end{abstract}

Keywords Eco-cement · Innovation · Policy · Circular economy · Sustainability · The Netherlands

JEL classification $\mathrm{L} 74 \cdot \mathrm{O} 33 \cdot \mathrm{O} 38 \cdot \mathrm{O} 52 \cdot \mathrm{P} 16 \cdot \mathrm{Q} 55$

Electronic supplementary material The online version of this article (doi:10.1007/s10368-017-0384-4) contains supplementary material, which is available to authorized users.

René Kemp

kemp@merit.unu.edu

1 United Nations University-MERIT, Boschstraat No:24, 6211 AXMaastricht, the Netherlands

2 Ellen MacArthur Foundation, 42 Medina Rd, Cowes PO31 7BX, UK 


\section{Introduction}

Concrete is the second most consumed material in the world after water. It is composed of aggregates (e.g. stone, gravel, and sand) and cement is the key ingredient binding these aggregates together through a chemical reaction induced by hydration (Sun et al. 2010). Cement is one of the most important building materials used for the production of concrete and mortar, and is globally crucial for securing the built environmental needs, such as housing and infrastructure-related needs. The cement industry is indeed a mature industry offering a homogenous product yet with different categories in terms of the performance characteristics. Price competition and product standards play an important role in the cement market, creating barriers to the production and use of eco-cement. In terms of competition, although there is an ongoing trend of globalisation, multinational actors still account for less than a third of the market share while the rest of the market is covered by small local cement producers (WBCSD 2002). One of the reasons for this situation is the proximity of production sites to the source of raw materials. This proximity is essential in cement production due to the high transportation costs over large distances. Another particularity of the cement industry is its low labour intensity due to automation. This situation allows for a large plant to employ even less than 200 people (WBCSD 2002). The cement industry ranks among the most capital intensive industries, the cost of a new plant being equivalent to three years' turnover (CEMBUREAU 2016a). Not only construction of new production facilities, but also modernisation of existing plants is expensive, with the typical investment cycle in the industry being 30 years (CEMBUREAU 2013b). In addition to these capital investment needs, almost a third of operating expenses are related to energy costs. The production of cement is a very energy intensive process using about $2 \%$ of the global primary energy consumption (Hendriks et al. 1998). The heat requirement ultimately depends on the type of process applied (wet or dry) as well as on the type of kilns used (rotary or shaft). In general, the production of the Ordinary Portland Cement (OPC), which is the most common hydraulic cement in use today, requires a temperature of $1450{ }^{\circ} \mathrm{C}$ inside the kiln to burn limestone (calcium carbonate). This ingredient is transformed during the process, known as calcination, into lime (calcium oxide) and forms together with other materials the main constituent of the cement: clinker (calcine) (CEMBUREAU 2016b). Additionally, the process of decomposing limestone for the production of the clinker is very carbon intensive. The carbon dioxide $\left(\mathrm{CO}_{2}\right)$ emitted from this process constitutes $60 \%$ of all production emissions. The other $40 \%$ originates from the energy produced by burning fossil fuels (CEMEX 2016). The carbon intensity of cement thus depends on the type of fuel used (ranging from petroleum coke, fuel oil and natural gas to alternative fuels), as well as on the clinker to cement ratio (Hendriks et al. 1998). The latter varies within the allowed standards. For instance, in the European Union (EU) between $95 \%$ of clinker content for CEM I Portland cement, through 65\%-94\% for CEM II Portlandcomposite cement, to 5\%-64\% for CEM III Blast furnace cement (CEMBUREAU 2013a, 2016c). On average, for each tonne of OPC produced, $0.9 \mathrm{t}$ of $\mathrm{CO}_{2}$ is emitted. Overall, the cement production has been estimated to be responsible for roughly $6 \%$ of global anthropogenic $\mathrm{CO}_{2}$ emissions (Imbabi et al. 2012).

From this introductory empirical background above, it follows that the cement production is facing major challenges in terms of reducing $\mathrm{CO}_{2}$ emissions. The industry has also recognised this need to lower the carbon footprint of the production processes 
and responded to the societal concerns regarding high $\mathrm{CO}_{2}$ emissions by launching the Cement Sustainability Initiative (CSI) (WBCSD 2002). This initiative by the major cement producers aims to establish a framework for sustainable development. Climate change mitigation stands at the centre of the CSI's strategy encompassing six work areas. One of the outcomes of this Initiative was the Cement Technology Roadmap 2009 drawn up jointly by the World Business Council for Sustainable Development (WBCSD) and the International Energy Agency (IEA) (WBCSD and IEA 2009). This roadmap outlines a possible transition path for the cement industry towards reducing direct emissions $18 \%$ from current levels by 2050 . To reach this objective the roadmap analyses four technologies (thermal and electric efficiency, alternative fuels, clinker substitution, carbon capture and storage), as well as the need to set up a policy framework and financial requirements. In line with this roadmap, the European Cement Association also formulated a vision of the European industry to reduce $\mathrm{CO}_{2}$ emissions by a third compared to 1990 levels (CEMBUREAU 2013b). Such reductions are envisioned to be achieved through conventional means of energy efficiency (both electrical and thermal energy) and resource efficiency (use of alternative fuels, raw material substitution, clinker substitution, novel cements, and transport efficiency). With the help of the successful deployment of emerging technologies such as carbon sequestration, a reduction of up to $80 \%$ by 2050 but diffusion is unlikely to begin before 2020 (IEA 2013). The vision report proposes initiatives further down the cement lifecycle, namely within the concrete and building industries. Finally, the recently published Low Carbon Technology Partnerships Initiative for Cement presents the ambition by the CEOs of cement companies to reduce $\mathrm{CO}_{2}$ emissions by $20-25 \%$ by 2030 compared to business as usual scenarios (WBCSD 2015). Their report discusses the key solutions to achieve this target, along with the barriers, stakeholders' involvement and policy requirements across the action plan with seven elements. Besides reiterating the energy and resource efficiency needs, the Initiative also calls for enhancing the coverage of sector's $\mathrm{CO}_{2}$ emissions and energy consumption database, developing new cements, engaging the building and infrastructure supply chain and evaluating the activities of cross-sectoral initiatives.

In terms of developing new cements, eco-cement takes many forms and is actually a label ${ }^{1}$ chosen for cement which uses waste as a fuel in its production and/or waste as an ingredient material in its final form/product. An example of the first strategy is the burning of sewage sludge, where the eco-benefit consists of the diversion of sewage sludge from landfills yet environmental benefits of this option are limited. An example of the second strategy is the use of waste as supplementary cementitious materials (SCM) derived from by-products of other industrial processes such as fly ash from coal production, blast furnace slag from iron and steel industry and silica fume which is a by-product of silicon and silicon alloys. This SCM-based cement is an eco-innovation because $\mathrm{CO}_{2}$ emissions from SCM-based cement are much lower than those from OPC based on lime stone because of the fact that the process of producing clinker from limestone is a very carbon intensive one. Eco-cement, thus, consists of many variations around the dominant product design of OPC as the most common type used in concrete

\footnotetext{
${ }^{1}$ Other commonly used labels are low-carbon cement, green cement or sustainable cement. None of the labels is precisely defined in the industry.
} 
for many purposes. Some variations of eco-cement are science-based and are created with the help of scientific research; other ones are created by industry with the help of experimental knowledge from tests, with a small role for science. Waste policies and resource availability at the local level are also two other sources of variation. As a lowvalue product, production of cement is dependent on locally available resources. This is why most cement production resides in the proximity of limestone excavations and industries whose by-products can be used. Further to the pathways for more sustainable cement production spelled out in industrial initiatives' documents, various applications in the production processes have been introduced in practice. These applications tend to differ across regions due to the differences in standards, regulations and practices, as well as in access to raw materials and climatic conditions across countries (CEMBUREAU 2013a). Among the more conventional improvements translated into practice is the use of alternative waste fuels such as wood and plastic from demolition activities, rubber tires, municipal sewage sludge and agricultural wastes. Another important trajectory is the use of supplementary cementitious materials (SCM). Besides reducing the amount mined material (primarily limestone) required for the production of cement, and the amount of waste that would need to be landfilled, using these SCMs in cement also improves the characteristics of cement as a product, in terms of its long term strength and reduced permeability (Paris et al. 2016). The most used SCM in clinker production are blast furnace slag, coal fly ash and silica fume. Though several others exist, such as rice husk ash, sugarcane bagasse ash, biomass combustion ash, palm oil fuel ash as well as burnt oyster shell and sewage sludge, these are however less utilised in practice (Paris et al. 2016). More radical innovations in form of novel cement compositions and technologies are currently under development. These types of cement are science-driven, originate from basic research and most of them are not deployed on large scales yet. An overview of trends and developments of new eco-cement types and technologies is provided in Schneider et al. (2011), Imbabi et al. (2012) and UNEP (2016).

The above characteristics of cement are essential for the analysis and discussion of innovation and innovation trajectory within the cement industry. In fact, the latter has been largely disregarded in the literature so far. This gap is mainly due to cement being a mature basic industry which is at the periphery of public attention. However, being a large polluter, the industry started to play a significant role in the climate change debates. The need for more ecological cement with more ecological production processes (known as eco-cement) has been recognised within various industry initiatives mentioned above. It is therefore important to understand the recent innovations and policy choices, trajectories relating to the cement industry. The more so, since many of these developments are based on the notion of circular economy, such as recycling and co-processing of wastes, they are thus indispensable for sustainable development in general. The cement industry is in itself a sector with a long history of using waste yet can still learn from and provide useful lessons for a circular economy. Eco-innovation depends on policy, and policy depends on (identified) eco-innovation opportunities and political economic factors. Eco-innovation activities and policy mutually influence each other but do not wholly determine each other, something which is captured in the notion of co-evolution (Van den Belt and Rip 1987; Kemp et al. 2007; Kemp and Pontoglio 2011). The central research question is: What is the influence of policy on the development and uptake of eco-cement in the Netherlands and to what extent have innovation possibilities in ecocement been utilised? Sub-questions are: what does the case of eco-cement learn about 
circular economy policy and what does the case of eco-cement learn about the political economy of innovation and governance of sustainability in the Netherlands?

This article proceeds as follows: Section 2 provides the theoretical background of our coevolution analysis and our theoretically-informed framework consisting of five core aspects relating to innovation trajectories. Section 3 provides information on data and method used in this article. In Section 4, we present an in-depth country case study of the innovation trajectory of eco-cement in the Netherlands: what this consist of, what role policy played in it and what factors prevented policy makers from better utilising innovation opportunities. In Section 5 we compare and contrast our empirical findings, and discuss what the case of ecocement can learn about circular economy policy, political economy of innovation and governance of sustainability in the Netherlands and the relevance of our framework and extending the future research directions towards innovation trajectories of eco-cement in different parts of the world, most importantly towards China and Japan.

\section{The link between innovation and policy: a streams perspective for co-evolution analysis}

Innovation is linked to policy in many ways: it is actively stimulated by research and innovation policy, it is shaped by product standards and sector policies, it depends on tax policies and government procurement policies. To put this multiplicity in perspective and create a theoretically-informed analytical/categorical framework, we reviewed the policymaking and change, and technological change literature.

\subsection{Policymaking and change literature}

From the perspective of policy-making and change literature, there are seven prominent theoretical/analytical models of policy-making which aim to explain the policy change. These models are the incrementalist model (Lindblom 1959, 1979), the punctuated equilibrium model (Baumgartner and Jones 1991, 2002), technical/rational model (Bridgman and Davis 2003), models of power and interest groups (Weiss 1983), policy networks (Rhodes 1990), advocacy coalition framework (Sabatier 1988; 1993; Sabatier and Jenkins-Smith 1993), and multiple streams framework (Kingdo 1984, 1995). Each model offers an analytical lens on policy as a process and on policy output. In each of those frameworks the interaction with technical change is not a focal element which makes those frameworks only partially relevant yet we further scrutinize these frameworks to illuminate and detect relevant aspects of the policy in analysing innovation: These are 1) that most policy consists of an adaptation of existing policies, 2) that policies reflect societal concerns which are taken up by political actors and policy agencies, 3) that responsibilities for policy issues (employment, environmental protection, innovation) are parcelled out (to ministries, departments who are competing with each other for money and for getting things their way, fitting with their programmatic tasks and wishes for power), 4) that policy choices need to be politically acceptable to society and in particular to special interests whose cooperation is needed for delivery, 5) that policy is based on ideas (about problems and the proper task for government with respect to intervention in the market process, for instance the degree to which they should have an arm's length relationship with business when it comes to issues of control), 6) that 
mechanisms for delivery requires detailed knowledge of a sector and is surrounded with uncertainty and the possibility of negative outcomes - where fears of policy failure usually leads policy makers to formulate unambitious policies and opt for selfmanagement models rather than strong regulations. The last element (which is often overlooked in political models of policy) brings into focus the importance of having technical knowledge about technologies, innovation possibilities and policy instruments and knowledge about the context of application, without which policies would result in inefficiencies, low effectiveness (goal achievement) and unintended outcomes.

In this paper, we use the most comprehensive framework (multiple streams framework) to illuminate relevant aspects of the policy in relation to innovation via technological change literature (Section 2.2) for a consistent and robust co-evolution analysis. The multiple-streams framework provides a useful theoretical/analytical framework to analyse the presence or absence of policy entrepreneurial activities in these interacting streams and subsystems, the windows of opportunities (narrow or broad) that are opened for both policy and technological change, through analysing the actors and/or institutions-based interactions between streams and subsystems (Zundel et al. 2005).

\subsection{Technological change literature}

Innovation requires effort and money and competes with well-developed alternatives (Kemp 1994). Product standards and interests in old technologies create additional barriers to innovation. Innovation is tied up with broader processes of change and coordinated action by innovation actors which include policy makers and intermediaries. In the innovation literature it is common to speak of the co-evolution of technology and the broader context. Examples arethe co-evolutionary model of Nelson (1994) about the co-evolution of technology, technology-supporting institutions and industry structures, the socio-cognitive model of technology of Garud and Rappa (1994) and, the quasi-evolutionary model of van den Belt and Rip (1987). In this paper we build on those approaches but offer greater attention to the policy: the use of selfregulation (in the shadow of control), support policies for innovation, product standards, and the effects of the interaction of different policy fields (e.g. circular economy policy) on innovation in eco-cement and the diffusion of different types of (eco-)cements, how these shape innovation choices and how such policies themselves are shaped by innovation possibilities and by the interests of cement actors.

Innovation activities, policy effects and political economy elements for the case of innovation in eco-cement in the Netherlands are described and discussed in relation to 1) (national) standards and regulations; 2) the EU emission trading systems; 3) circular economy and other policies; 4) (scientific and applied) research and innovation; 5) civil society action, and 6) the market demand. Instead of opting for a broad scoped analysis (as done in Nelson (1994) and Zundel et al. (2005) we opt for a detailed analysis of the influence of the above 6 elements. Our unit of analysis is innovation in eco-cement of which we study the trajectory of change and key elements from the politicoadministrative window, techno-economic window and socio-cultural window. ${ }^{2}$

\footnotetext{
${ }^{2}$ In so doing, the framework extends the more narrow five frameworks mentioned in section 2.1. A description of the different frameworks and their link with the 6 elements can be found in the Supplement file.
} 


\section{Data and method}

The choice of analysing the innovation trajectory of eco-cement in the Netherlands is motivated by the presence of well-established eco-cement initiatives in the country. The Netherlands has also introduced circular economy processes, which are at the heart of these eco-cement initiatives. In particular, the Netherlands is also known for substituting a significant share of fuels by alternative sources (WBCSD and IEA 2009). Additionally, the Netherlands is also the EU Member State with the highest share of cement with lower clinker content due to its century old historical experience with blast furnace slag cement (CEM III) production and deployment, e.g. in marine applications (CEMBUREAU 2013a).

The sources of secondary data are recognized organizations and initiatives such as CEMBREAU, WBSCD, IEA. The data is obtained through desk research. The field research consisting of interviews is the main method of obtaining primary data in this article and they are conducted between January and March 2017. The data are processed in innovation and policy trajectory narrative in Section 4 . This narrative is event-based and uses theoretical notions as well as core aspects mentioned in Section 2, namely standards and regulations; emission trading systems; circular economy and other policies; (scientific and applied) research and innovation; and the market demand. The influence of policy and innovation interactions are substantiated based on interviews with relevant eco-cement actors, policy documents, media news items and analysis of patterns of eco-cement use. For reasons of space, we included supplementary data in the form of tables and figures in a supplementary file.

All innovations analysed in this article relate to resource efficiency improvements achieved through the use of waste as alternative fuel, through the reduction of clinker factor by substitution by fly ash and GGBS (and possibly silica fume), and through novel composition of cements (possibly CSA and possibly alkali-activated). We do not analyse energy efficiency improvements in terms of thermal and energy efficiency since these are mainly related to individual firms' initiatives and tied to capital costs with long investment cycles. We also do not investigate the breakthrough technologies like CCS\&U since these have not been deployed commercially on large scale yet.

\section{The Netherlands: innovation and policy trajectory of eco-cement}

\subsection{Standards and regulations as shapers of cement choices}

The Netherlands have almost a century of historical experience in the use of ground granulated blast furnace slag (GGBS) cements with high slag content, comparable to current CEM III/B (66-80\% slag) as defined in EN 197-1 (2011) for major infrastructure, including marine concrete and "under Dutch climate conditions, any freeze-thaw + de-icing salt damage of concrete is very small and the performance of CEM III/B and CEM I concrete are considered to be similar with regard to this aspect" (TNO 2014). In the Netherlands, as opposed to most other European countries, the penetration of the OPC (CEM I) has been relatively low, with a market share of below 25\% between 1990 and 2007 (CEMBUREAU 2013a). Instead, the main cement type produced is the CEM III standard blast furnace slag (BFS), constituting almost $70 \%$ of the current market 
share. Its usage in the Netherlands dates back to the 1920s when the North Sea canal locks at IJmuiden were constructed (Polder 2012). The production itself was established in 1931 with the setup of the CEMIJ plant at IJmuiden - a joint production by the cement producer ENCI and the iron producer Hoogovens (Polder et al. 2013). Its location has been strategically chosen to be close to Amsterdam, what assures a more convenient and ecological way of transportation of materials by waterways, as well as close to steel producing industry, assuring access to raw materials. In fact, BFS is a byproduct of the pig-iron production and is sourced from the neighbouring facility today's Tata Steel (ENCI 2014a). Another remarkable fact is that in 2014 the use of alternative raw materials for the production of various blast furnace cements reached $64 \%$ across all ENCI cement producing plants (ENCI 2014a).

In terms of regulations concerning the use of blended cements in the Netherlands, these have evolved from initially prohibiting the slag use in cement (1912), to being continuously more liberal and allowing use of the slag upon a prior consent by the client and the contractor (1930, 1940 and 1952 regulations). The 1962 regulation was the first to grant free choice of cement types, while the 1984 regulation has explicitly recommended the use of slag cement in aggressive environments and discouraged the use of OPC. In particular, cement with at least $65 \%$ of slag content has been recommended for use within marine environments by the 1986 concrete technology standard (Polder 2012). The Netherland's specific geographical conditions with open water landscapes and moist and salty environments require cements with high durability, and especially better resistance to aggressive substances (Global Cement 2012). It is indeed mainly in marine environments where the BFS cement has demonstrated its superior characteristics as compared to OPC, within long life projects such as roads, bridges and tunnels, as well as in buildings near the sea. Besides the geography of the country, another reason for the high penetration of this cement type was the access to raw materials. Netherlands lacks significant deposits of limestone, what is the main input material to the production of OPC. In fact, most of its cement has been produced from imported clinker, mainly from Germany and Belgium substances (Global Cement 2012). While most types of cement are based on Portland cement clinker, the BFS cement is made by adding other materials to it, especially slag but also fillers such as pulverised coal fly ash and furnace dust. Depending on the cement type, the ratio of BFS can vary between $25 \%$ and $70 \%$ (CEMBUREAU 2013a, b). Taken together, these developments led to the blast furnace slag cement, also known as the CEM III standard, to become the dominant standard already in the 1970s. At present its market share is around $70 \%$ in the Netherlands and the main producers are ENCI IJmuiden and Rotterdam.

Fly ash (also known as pulverised fly ash (PFA) or the CEM II standard) blended cements have emerged in the Netherlands during the 1980s and their composition relies on the residues of coal-fired power plants. The first studies on fly ash were carried out in the 1990s and have found that, similar to replacing clinker by slag at high levels (up to $70 \%$ ), also the replacement by fly ash (up to $30 \%$ ) resulted in cements with superior characteristics, in terms of their high resistivity and low corrosion rates as compared to OPC in chloride contaminated environments (Polder 2012). Yet, the emergence of fly ash cements dates back to a decade earlier and could be considered as an indirect result of the oil crisis in the 1970s. In fact, as a response to the high oil prices the Dutch decided to switch away from oil-fired to coal-fired power plants, increasing their share from $10 \%$ to $40 \%$ in the 1980 s (Woolley et al. 2000). By burning coal, the main by- 
products are various types of pulverised ashes which are collected by the electrostatic precipitators. Yet, these were not allowed to be landfilled, in line with the Dutch policy on Sustainable Construction. In particular, the Integral Substance Chain Management introduced the idea of circular economy and was aiming at minimum materials being dumped and maximum of the by-products being reused, limiting thus also the extraction of primary materials. Additionally, since 1996 dumping materials which might still have been re-used was no longer allowed in the Netherlands (Cox et al. 2008; Klostermann et al. 1998). The energy generating industry responded to this by establishing a joint company called Vliegasunie (Dutch Fly Ash Corporation) in 1982. Its purpose was to market the industrial by-products of the Dutch power stations, mainly fly ash, bottom ash and FGD gypsum, for the re-use within the construction industry and civil engineering (Vliegasunie 2016). Besides storage and logistics, Vliegasunie also assures the quality of products through safety information sheets and certificates of constancy of performance produced, in order to meet the requirements of the construction industry. On the other end, the acceptance of the re-use of ash as part of the building industry had to be in line with the Dutch Civil Engineering Centre for Research and Regulation (CUR 1998) as well as the Dutch decree on Building Materials (1995). The latter stipulates the use of by-products in building materials, in particular with regards to soil pollution due to leaching of materials (Eikelboom et al. 2001). It was replaced in 2008 by the Dutch Decree on Soil Quality (Van Eijk and Brouwers 2002; Van Eijk et al. 2011). Besides national regulations, the fly ash utilisation has also to satisfy regulation at European level. In particular, based on the Construction Products Regulation, only fly ash from pulverised coal combustion is admissible for the use in cements with up to $10 \%$ of co-firing of alternative fuels (Vliegasunie 2016). Yet, the Vliegasunie has obtained CE markings for using fly ash with co-firing of up to $50 \%$ depending on the co-combustion material (BMC Certification 2004). This ultimately allows broadening the scope of using fly ash within construction. Finally, besides standards for cement, fly ash cements also have to meet requirements for the EN 450 regulation on fly ash for concrete (Feuerborn 2005). Besides the Dutch Fly Ash Corporation, the representation of industry's interests on the European level had a significant impact on fly ash remaining an established construction raw material (ECOBA 2016; EURELECTRIC 2012; European Commission 2000).

While the above have contributed positively to the emergence of alternative cement compositions in general, and to the deployment of fly ash cement in particular, some other factors inhibit the take-off of this technology on large scale. To start with, the strong position of the OPC cement type (though its relative share is lower within the Netherlands than in other countries) is guaranteed by international standards. The European Standard EN197-1 defines requirements on the basic composition for fly ash (CEM II) and limits these cements to contain 6-20\% and 21-35\% of fly ash for CEM II/A CEM II/B, respectively. Whereas in case of the composite cements CEM V/A and CEM V/B this ratio might increase up to $50 \%$ (European Committee for Standardization 2000). The fact that this standard was first adopted in the 1992 and then only revised in 2000 points to the rigidity of the composition based standards in Europe. ${ }^{3}$ This ultimately causes that novel cement compositions have it very difficult to compete on the market, without them being established as standards in a mature

\footnotetext{
${ }^{3}$ In the supplement, European standards for cement and concrete are described.
} 
industry. An example of a novel cement composition which substantially reduces the limestone content during clinker production, and thus the energy intensity of the process and the CO2 emissions, is the ASCEM cement (ASCEM 2009). This uses alkali activated slag cements instead of Portland clinker, made from specially manufactured hydraulic slag of fly ash, limestone and additives. These are later mixed with filler materials (mainly coal fly ash, but also sand or blast furnace slags are possible) and a small quantity of alkali activator. The cement is thus characterised with very high content of secondary raw materials (up to $70 \%$ of mainly fly ash). Besides environmental aspects, the ASCEM cement is also claimed to have superior characteristics in terms of low heat of hydration in concrete, improvement of mortar strength at elevated temperatures and soundness against sea- and wastewater (ASCEM 2009). Due to the major obstacle hindering the adoption of alkali activated technology being the missing standards (as exist in case of traditional cements), the Alkali Activated Materials Committee of the International Union of Laboratories and Experts in Construction Materials, Systems and Structures has been set up, in order to develop performance-based specifications and recommendations for the development of such standards specifically applicable to these new materials (RILEM 2007). Another example of a novel cement composition created in the Netherlands is the thermoplastic carbon-based cement (carbon fixation or C-Fix). The latter is also is a great example of public-private cooperation. The product itself has been developed from an initiative of a private company Shell in cooperation with the Delft University of Technology. It is made from the by-product of the oil refinery and ranks thus among organic cements, as opposed to all previously discussed cements types (Woldekidan 2006). According to the developers, the carbon footprint of this cement is 3.5 times lower than that of the OPC. On the downside, this cement composition is temperature and pressure sensitive, what makes it unsuitable to substitute OPC in general. However, it may be considered as a replacement for asphalt in road surface, for concrete in industrial flowing, as well as used in marine environments (MPA Cement 2013). The main barriers to the deployment of these novel cements are thus the competition from the established cement (in terms of established standards and the resistance from the construction sector), slow formal certification for novel cements, as well as higher capital / process costs of manufacturing (due to economies of scale in production), in some cases inferior performance and durability characteristics when compared to OPC, and the global distribution of raw materials required for their production (Dewald and Achternbosch 2015; MPA Cement 2013). Additionally, the traditional cement industry continues to receive free allowances within the EU Emissions Trading System (EU ETS). This is claimed to prevent carbon leakage, yet it also incentivises the industry to lock in $\mathrm{CO}_{2}$ intensive cement production processes. Consequently, such measures distort the competition on the market by introducing a competitive disadvantage to alternative cement compositions relative to OPC (European Commission 2014). (See below Subsection 4.1.2 for further discussions).

\subsection{The EU emission trading system}

Emission Trading System and Cement Industry in the EU: Launched in 2005, Emission Trading System (ETS) covers nearly half of all EU $\mathrm{CO}_{2}$ emissions, $45 \%$ of greenhouse gas emissions. It is a mandatory scheme for all 28 EU members and three EEA-EFTA states, Iceland, Liechtenstein and Norway. The target of the system is $21 \%$ emissions 
cut below 2005 levels by 2020. Between 2005 and 2007, the system experienced its test period, the 1st phase. The 2nd phase ended in 2012 (2007-2012), and up until 2020, the 3rd phase will be running (2013-2020). In the system, Member States allocate a quota of carbon emission permits to some 11,000 industrial firms and power plants (EC 2016). About half of these permits are auctioned from 2013. According to Sandbag, a climate policy think tank, the rules governing free allocation of allowances in Europe have failed to incentivize $\mathrm{CO}_{2}$ abatement in the cement sector due to the sector's inclusion on the list of sectors exposed to the risk of carbon leakage, insensitivity to production changes, and resulted in over-allocation (Sandbag 2016; Walsh 2016). Smaller cement producers, like ECOCEM, have also criticized the EU ETS for slowing a transition to a low carbon economy by de facto subsidizing the larger producers' emissions through over-allocation. ${ }^{4}$ The Netherlands distributes the free carbon permits to the industrial manufacturers regulated by the EU's Emissions Trading System (ETS), such as steel and cement producers, by the Dutch Emissions Authority (NEA). A total of 43.7 million permits have given to 374 Dutch companies over February 26-27 2016, which is a traditional date and month to receive annual allocations, the end of February (Reuters 2015; NEA 2016).

The rationale behind distributing free carbon allowances is to help industries to be able to compete with the rivals which operate under looser environmental regulation regimes in other countries however the allocation of EU Allowances (EUAs) is also thought to be adding a supply to a market already oversupplied with permits and could put more pressure on carbon prices, which were below 7.50 euros a ton in 2015 (Reuters 2015) and are dropped to 6 euros in January 2016 (Politico 2016). We observe a slight reduction pattern in the free (emission rights) allocations (2013, 14.524 EUA/year to 12.700 EUA/year in 2020 for ENCI BV Ijmuiden, and 598.225 EUA/year in 2013 to 523.310 EUA/year in 2020 for ENCU BV Maastricht) up until 2020 to ENCI in the Netherlands. One might further inquire whether this situation resulted in windfall gains.

\subsection{Circular economy policies}

Co-incineration of waste The circular economy package of the EC as an umbrella package covers a wide variety of proposals from waste recycling to resource-efficient buildings. According to CEMBUREAU both the cement and concrete industry apply the principles of the circular economy throughout their life cycle. This is done in two ways:. by using waste as a fuel instead of coal and petcoke and through the use of supplementary material. CEMBUREAU claims that the concrete is $100 \%$ recyclable (CEMBUREAU 2014a, b), since at the end of its life, concrete can be recycled either back into concrete as a recycled aggregate or into other applications (e.g. a road base). However, it is also states that concrete demolition waste can only meet around $30 \%$ of their aggregate needs. Therefore, in order to make new concrete, primary aggregates will still be required (Global Cement 2012). In the Netherlands, co-processing

\footnotetext{
${ }^{4}$ According to the Sandbag's report, the 2020 targets under the EU's Renewables Directive alongside the Waste Framework Directive and Landfill Directives, as part of circular economy package, are more of an incentive for moving towards low-carbon cement than the ETS (Sandbag 2016).
} 
includes mainly organic waste, for example sewage sludge and bone meal, as well as paper and plastic-derived fuels (PPDF). In particular, in ENCI Maastricht biomass constituted $33 \%$ while other alternative fuels $45 \%$, as compared to fossil fuels with $22 \%$ share of total fuels used in 2014. The ratio of biomass has increased from $0 \%$ in 1996 to 44\% in 2007 and has ever since been on decrease (ENCI 2014b; Junginger 2009). The most dominant fuel is dried sewage sludge which is sourced both from close but also more remote areas in the north of the Netherlands. The first mill to grind sewage sludge (BioMill) was commissioned in 2000 as a joint venture of ENCI and Waterschapsbedrijf Limburg, which is the main supplier of sewage sludge. The construction of the second one started in 2003 to accommodate processing sludge from other parts of the Netherlands (Dagblad de Limburger 2003a). As for the other organic sources: paper sludge in turn is sourced as a waste product from the local paper plant in Maastricht, while animal meal and PPDF are transported $100 \mathrm{~km}$ distance each, from Brabant and Germany, respectively (Junginger 2009). In spite of these, the use of biomass is expected to remain low in the near future, due to the change in clinker production and the availability of alternative fuels. The use of biofuels as a source of alternative to fossil fuel energy sources is largely in line with the EU strategy on biofuels, which stipulates that Member States shall eliminate practices that act as barriers to the introduction of biofuels (EC 2006). The non-discrimination against use of renewable energy has further been confirmed by the EU Renewable Energy Directive (European Parliament 2009). However the latter is largely focused on the use of biofuels industry and electricity power generation only and disregards the cement industry altogether. This in turn has been identified as the main source of distortion in sourcing biomass as alternative source of energy for cement production (Maringolo 2009). Yet the evidence from Belgium on cement plants co-processing contaminated animal products in the late 1990s demonstrated that co-processing could be a valuable solution to a societal problem (Maringolo 2009). Indeed, at the times of the BSE-crisis, the Dutch Government approached the ENCI Maastricht plant about the possibility of co-incinerating animal meal in cement kilns. Subsequently, the Province of Limburg granted the license to ENCI Maastricht in 2002 for burning 20.000 tons of animal meal annually. The advantage for the cement plant was in terms of using waste as alternative fuel and collecting monetary compensation for burning it, and for the society in terms of not having to think of other modes of disposal of contaminated meal. Yet the local environmental organisations Enci Stop and Milieufederatie Limburg launched opposition against burning biomass due to the potential emission of carcinogen dioxins. This has however been dismissed by the Supreme Court (Limburgs Dagblad 2002a).

The recycling of concrete The recycling sector deals with concrete waste in several ways. They produce recycling aggregates from concrete which they sell to the concrete industry as a material (concrete aggregate) and to road builders as a road construction material. The larger parts are sold to the concrete industry, the small parts are used in road construction but there is too much of this, which they hope to also sell to the cement industry (the concrete industry is interested only in bigger parts). The landfill ban of concrete waste is the main factor behind the diversion of concrete waste from landfills. The recycling industry uses a 3-stage approach for the recycling of concrete waste. The 1 st phase is road construction, 2nd phase is producing concrete with recycled concrete aggregates inside, and the $3 \mathrm{rd}$ phase is smart crashing to produce 
new type of cement. Selling concrete waste to the cement industry is not easy as they prefer to use primary material from their own mines. The recycling industry developed into a process industry, whose quality is increasing over time thanks to innovations in separation and treatment. National government supports the use of recycled materials in road foundations, in buildings, but local government and inspectors, and people in general at local level show a considerable degree of resistance in faster acceptance.

\subsection{Research and innovation in new types of cement in the Netherlands: industrial innovation and scientific and applied research}

In this section, we offer a discussion of the innovation networks behind the innovations. From an impact point of view, the most important innovations in cement are the substitution of Portland clinker by blast furnace slag and fly ash and the substitution of dried sewage sludge and bone meal for fossil fuels in the incineration process. The use of blast furnace slag already started in 1917 at the Hoogovens steel factory site (now Tata IJmuiden). The use of fly ash as a substitute for lime stone began in the 1980s. It was sparked by the landfill ban on fly ash leading coal-using power producers to look for alternatives. For this purpose they created in 1982 the Vliegasunie, as the commercial arm acting from a monopoly position as far as Dutch fly ash is concerned. For policymakers, the use of fly ash in cement was seen as economically and environmentally advantageous. For cement producers the negative price for fly ash made it an attractive material to use. Cement producer and market leader ENCI even expected fly ash to replace Portland cement in 3 to 4 years but this did not happen, in part because of competition of Portland cement from abroad (Groen 1987 p. 74).

Two other innovations are Via Verde concrete and ASCEM cement. Via Verde concrete is used for concrete foot paths, bicycle paths, parking place and secondary roads. ${ }^{5}$ It is developed by a special partnership of BAM Wegen, IntroVation, ORCEM en Van Nieuwpoort, with support of the province Utrecht. The combined use of fly ash and furnace ash helps to achieve a $\mathrm{CO}_{2}$ reduction of $80 \%$ compared to OPC according to sustainability manager Tom van den Nieuwenhuijzen. ${ }^{6}$

ASCEM cement consists of a potential reactive hydraulic slag (47.5\%), filler composed of coal fly ash (47.5\%) and an alkali activator. The ASCEM slag is produced by high temperature process of a mixture of $57 \%$ limestone and $40 \%$ fly ash. With $36 \%$ limestone, ASCEM cement process uses far less limestone than Portland cement (90$95 \%$ limestone) and also even less then blast furnace cement (50\% limestone). $\mathrm{CO}_{2}$ emissions are more than 50\% lower than OPC, and slightly below those of blast furnace cement. The smelting process to produce a glass type of slag makes it more expensive than traditional fly ash cement. ASCEM was unhappy about the grandfathering of carbon emission rights under the ETS (allowing other cements to undercut the ASCEM cement price-wise) but was not in a position to do something about it. They could not stage a policy window for their product. The use of ash from the burning of sewage

\footnotetext{
${ }^{5}$ For further information, please refer to ViaVerde (in Dutch) http://www.viaverde.nu/flyer ViaVerde.pdf

${ }^{6}$ For more information, please refer to the news brief (in Dutch) http://www.mt.nl/series/beton-kan-veelgroener/63231
} 
sludge in cement kilns (as a minor innovation) is the direct result of the decision to use sewage sludge as a fuel for cement production. After dewatering and drying the sludge at municipal waste-water treatment sites, the organic material is being grinded in a special plant of BioMIll, a joint venture of the Limburg association of water management boards (Zuiveringsschap Limburg) and ENCI (Erens et al. 2003). The use of sludge by the cement industry is thus the result of a special economic partnership. The co-incineration of sewage sludge was threatened by the tightening of mercury emission standards by a factor of five as proposed by the Minister of Environment Pronk, in view of health considerations of local residents. Such tightening below the EU standards would have substantially limited the burning of sewage sludge in cement kilns in the Netherlands, which have been shown to contain a substantial amount of mercury. However, the new Minister of Environment Geels withdrew the proposal in favour of the old standards which are in line with the European directive on incineration of waste. This decision was based on the environmental impact assessment indicating that coincineration of sludge was the most environmentally-friendly method of disposal (Limburgs Dagblad 2002c) but in this he was pushed by the political lobby for ENCI, through the CDA party whose chairman had been previously in the executive committee of the Zuiveringschap Limburg, which delivers the sludge, and in the management board of BioMill, which grinds it (Limburgs Dagblad 2002b). The closing of a technoeconomic window was thus circumvented through political action. The window itself was related to the EC directive 1999/31/EC on the landfill of waste (which discouraged the landfilling of organic matter) and the costs of other options (such as burning the sludge in waste incinerators.

The Netherlands is also active in international scientific and applied cement research. An overview of European projects is given in Table 1.

The science and research agenda has its own autonomy but also is influenced by policy agendas, such as climate policy, the resource efficiency roadmap, and for Dutch actors, the closure of the ENCI quarry and the Green deal ${ }^{7}$ to make concrete more sustainable, and circular economy policies (MVO Nederland 2016). There is a political economy element also in research. The Heidelberg group (of which ENCI is a part) studies alkali-activated cement in a covert way (source: interviewee). An investigation of the costs of ways to make the concrete chain more sustainable is limited to those options in which the sector is commercially interested in, showing the influence of the industry on the options for consideration. The use of CCSU (carbon capture and sequestering and utilization) and the use of less concrete in construction works were excluded from investigation for strategic reasons (van der Vooren et al. 2015 p. 20). Companies are worried about that the inclusion of those options may lead to policies in support of those options.

\subsection{Civil society actions}

In the Netherlands, limestone is excavation is limited to a few locations with limestone deposits. Currently limestone is only being extracted by ENCI from the caves in

\footnotetext{
${ }^{7}$ The green deal is a covenant about making the concrete chain more sustainable, in which the Dutch government and 7 sectors involved in the production and use of concrete promise to take action.
} 


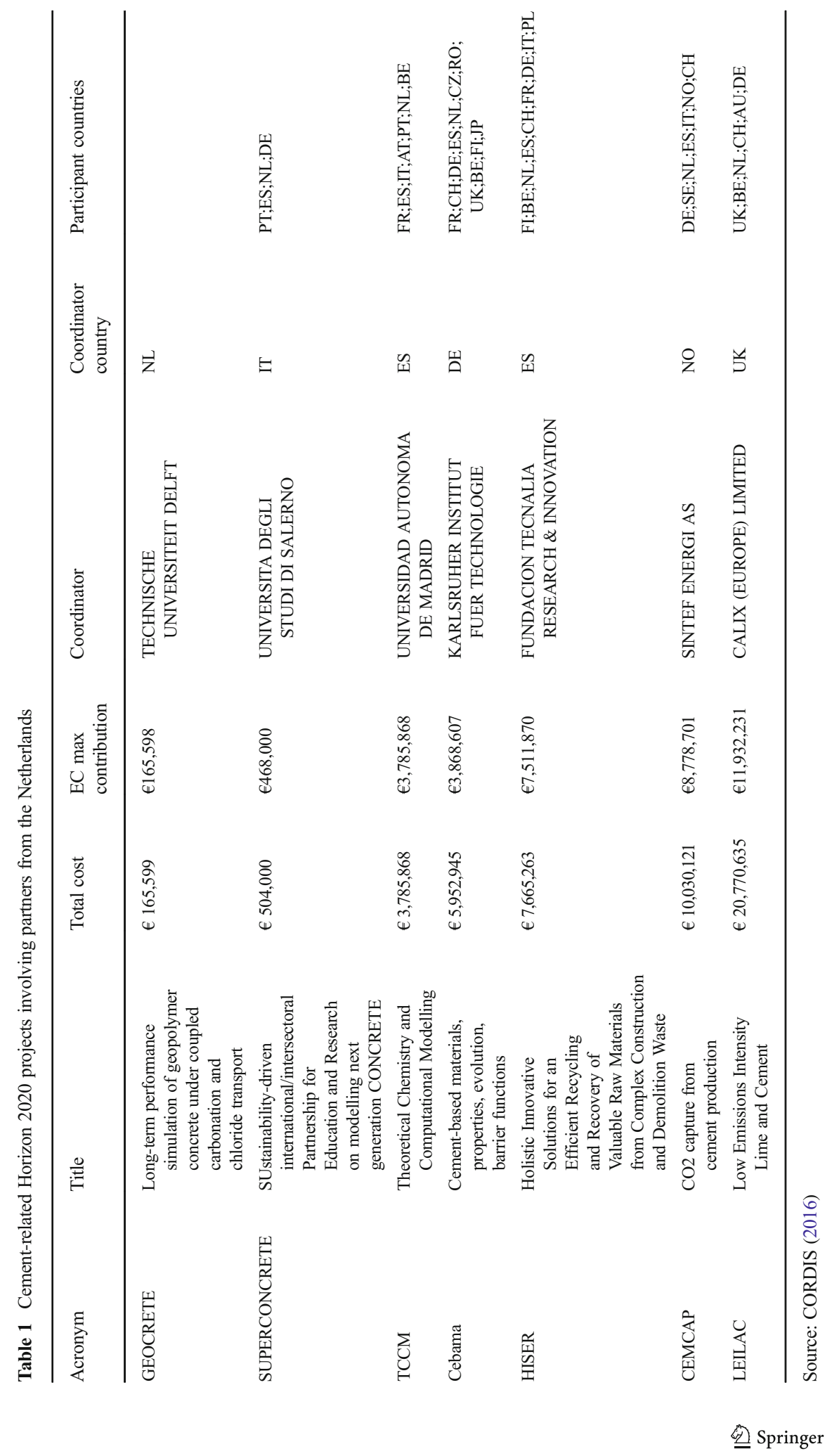


Maastricht, where 997 thousand tons of marl are being excavated for the production of 559 tons of clinker in 2014. The plant has a license to continue extracting limestone from its St. Pietersberg quarry until 2018, and to produce clinker until 2019. After this date the site will turn into a recreational area (ENCI 2014b).

The closure of the quarry and clinker production is a result of various factors: many years of protest to excavation and the co-combustion of waste by local residents and environmental activists, the bad economies of the company as well as the adverse market conditions (Dagblad De Limburger 2008). A major role though was played by the civil society from both the Netherlands and Belgium, which was pointing to the environmental damages caused by mining limestone, in terms of air pollution, odour, dust and noise nuisance, as well as soil contamination and decline of groundwater levels and the quality of the Belgian drinking water, and the endangered flora and fauna (Dagblad de Limburger 2003b, 2004a, b, c; Het Belang van Limburg 2003). The opposition, led by ENCI Stop and Sint Pietersberg Adembenemend environmental organisations, peaked when ENCI Maastricht applied for the extension of mining concession till 2030 and possibly beyond and also for the allowance for deeper mining (Dagblad De Limburger 2007; de Trompetter 2007; Enci Stop 2001; Het Belang van Limburg 2004). Yet, based on the results of the environmental impact assessment, ENCI's request for mining $40 \mathrm{~m}$ deeper has been denied by the Province of Limburg (ENCI 2004). Furthermore, the extension of the mining permit has only been granted till 2018 based on an agreement between ENCI, the Province, the Municipality as well as the environmental organisations (Dagblad Trouw 2008; NRC-Handeslblad 2009). Yet, ENCI will continue producing cement at its Maastricht site with the use of imported clinker. Therefore, the potential for future decrease of dependence on imported raw materials is becoming ever more prominent. In order to make the production process less energy intensive and to decrease the use of primary material, ENCI Maastricht is already now using by-products from other industries to replace clinker in its cements, among others fly ash. In this respect, there are several R\&D initiatives driven by the industry: cement research is carried out in ENCI Maastricht, while concrete research occurs at ENCI Rotterdam and at the Sustainable Concrete Centre (Cementbouw 2016; ENCI 2014b). Furthermore, the Cement\&Beton Centrum represents the interests of the Dutch cement industry through market research, communication, knowledge transfer, technical research and regulation (Cement\&Beton Centrum 2016).

\subsection{Market demand for eco-cement: dynamics of take up}

Demand for low-carbon cement such as alkali-activated cement is low but growing thanks to the interest from local authorities and housing corporations in this. The availability of cheap slag and fly ash resulted in the use of those materials but this was entirely for economic reasons, not for environmental reasons. To help contractors more greener cement choices, a system is created which translates all environmental costs in a single indicator (MKI - Milieukosten indicator). The MKI is calculated with special software. A low MKI offer a prime premium in the form of a virtual price reduction, which under the obligation for the government to buy the economically most advantageous products (EMVI - Economisch meest voordelige inschrijving), stimulates green cement. The effects of the MKI in combination with EMVI are small, since the real price is usually the decisive factor (van der Vooren et al. 2015, p. 22). Another 
negative factor working against new types of cement is that the specification of the concrete is taken up in the specifications and conditions of a project at a relatively late stage. The use of rules, labels and norms introduced for quality assurance reasons works against new types of cement (van der Vooren et al. 2015, p. 22). As a related factor, many clients ask for cement that meets the CUR-100 norm, even when this is not needed. The possible closure of Tata IJmuiden and coal-fired plants in the Netherlands may lead the sector to shift back to Portland cement, even when this has to be imported after the closure of the Sint Pieter quarry. Portland cement is likely to hold a strong foot into the market in the absence of a carbon price.

\section{Concluding remarks}

In this paper, we described the considerations behind innovation in eco-cement, with special attention to the role of public policy, civil society action and industry interests. We found that events in neighbouring fields, such as waste management, circular economic policies, higher fossil fuel prices, exchange rate changes and building standards and regulations played an important role, far more than lowcarbon policies. In the Netherlands, the use of alternative materials in cement benefitted from bans on waste disposal for fly ash, sewage sludge and more recently the landfill ban on concrete waste, leading the producers of such waste to collaborate with cement companies.

The main type of cement used is blast furnace slag (BFS) cement, which is quite exceptional. Reasons behind this are the superior technical performance in moist and salty marine environments and availability of blast furnace slag as a cheap material, owing the landfill bans. New cement types such as Alkali activated cement however are found to suffer from various barriers such as a revision of product standards based on comprehensive tests and the absence of a carbon tax which would provide it with a competitive advantage.

The trajectory of innovation in eco-cement confirms the multiple streams model of Zundel et al. (2005) that says that for a green innovation to come to fruition, different windows need to align. Alignment of the techno-econmic window with the politico-administrative policy window was achieved through various kinds of cooperative actions between waste producers and the cement industry. An important finding is that strong waste policies are the main reason for why the Netherlands has a low share of OPC and a high share of cocombustion. This insight is of relevance to other countries which want to promote low-carbon cement such as China, but each country has its own techno-economic, politico-administrative and social-cultural circumstances. China's commitment to circular economy and carbon emission trading could facilitate eco-cement. Whether this will provide an equally strong impetus as waste policies in the Netherlands remains to be seen.

Acknowledgements This article was prepared as a part of SINCERE (Sino-European Circular Economy and Resource Efficiency) project received funding from the NWO (The Netherlands Organisation for Scientific Research). This article has also benefited from valuable comments provided by the members of SINCERE consortium, especially by Raimund Bleischwitz and Will McDowall of University College London (UCL), and Prof. Geng Yong of Shanghai Jiao Tong University. 
Open Access This article is distributed under the terms of the Creative Commons Attribution 4.0 International License (http://creativecommons.org/licenses/by/4.0/), which permits unrestricted use, distribution, and reproduction in any medium, provided you give appropriate credit to the original author(s) and the source, provide a link to the Creative Commons license, and indicate if changes were made.

\section{References}

ASCEM (2009) ASCEM cement. ASCEM special technologies. Retrieved from: http://www.ASCEM. nl/upload/file/1264409105.pdf

Baumgartner FR, Jones BD (1991) Agendas and instability in American politics. University of Chicago Press, Chicago

Baumgartner FR, Jones BD (2002) Policy dynamics. University of Chicago Press, Chicago

BMC Certification (2004) Fly ash for concrete - ETA request No 03.01/34. Retrieved from: http://www. vliegasunie.n1/engels/downloads/certification/fly/CUAP_FLYASH_03-01-34.pdf

Bridgman P, Davis G (2003) What use is a policy cycle? Plenty, if the aim is clear. Aust J Public Admin 62:98-102

CEMBUREAU (2013a) Cements for a low-carbon europe Retrieved from http://www.cembureau. be/sites/default/files/documents/Cement\%20for\%20low-carbon\%20Europe\%20through\%20clinker\%20 substitution.pdf

CEMBUREAU (2013b) The role of cement in the 2050 low carbon economy Retrieved from http://lowcarboneconomy.cembureau.eu/uploads/Modules/MCMedias/1380546575335/cembureaufull-report.pdf

CEMBUREAU (2014a) Activity report 2014. Retrieved from http://www.cembureau. eu/sites/default/files/Activity\%20Report\%202014 website 1.pdf

CEMBUREAU (2014b) Cement, concrete \& the circular economy. Source: http://www.cembureau. eu/newsroom/article/cement-concrete-circular-economy

CEMBUREAU (2016a) Cement industry - main characteristics. Retrieved 05-03-2016, from http://www. cembureau.be/about-cement/cement-industry-main-characteristics

CEMBUREAU (2016b) Cement manufacturing process. Retrieved 05-03-2016, from http://www.cembureau. be/about-cement/cement-manufacturing-process

CEMBUREAU (2016c) Product standards \& regulations. Source: European Standards for Cement and Concrete http:/www.cembureau.be/topics/sustainable-construction/product-standards-regulations

Cement\&Beton Centrum. (2016) Wie we zijn. Retrieved 11-04-2016, from http://www.cementenbeton.nl/cbc/wie-we-zijn

Cementbouw (2016) Sustainable concrete centre. Retrieved 11-04-2016, from http://www.cementbouw. $\mathrm{nl} / \mathrm{mvo} /$ Sustainable Concrete Centre

CEMEX (2016) CEMEX and EU ETS Retrieved from: http://ccap.org/assets/Javier-Merle_CEMEX.pdf

CORDIS (2016) GEOCRETE Retrieved from http://cordis.europa.eu/project/rcn/200952_en.html

Cox M, Nugteren H, \& Janssen-Jurkovičová M (Eds) (2008) Combustion residues: current, novel and renewable applications. John Wiley \& Sons

CUR (1998) Toepassing van Poederkoolvliegas in Mortel. States Vegvesens. Retrieved from http://www.curaanbevelingen.nl/CUR-Aanbeveling-066

Dagblad de Limburger (2003a) ENCI: Nieuwe Installatie voor Verbranden Slib. Retrieved 24-04-2016, from http://www.6212hp.nl/SES-archief/krant/overz_div14.htm\#top

Dagblad de Limburger (2003b) Toename Klachten over ENCI. Retrieved 24-04-2016, from http://www.6212 hp.nl/SES-archief/krant/overz div10.htm

Dagblad de Limburger (2004a) Belgen Vrezen Vuil water. Retrieved 24-04-2016, from http://www.6212hp. nl/SES-archief/krant/overz_div15.htm\#top

Dagblad de Limburger (2004b) Bezwaren tegen ENCI-Vergunning. Retrieved 24-04-2016, from http://www.6212hp.nl/SES-archief/krant/overz div15.htm\#top

Dagblad de Limburger (2004c) Milieufederatie Steunt Verzet tegen ENCI. Retrieved 24-04-2016, from http://www.6212hp.nl/SES-archief/krant/overz_div15.htm\#top

Dagblad De Limburger (2007) Bijna 10.000 Keer 'Nee' Tegen Plannen ENCI. Retrieved 24-04-2016, from http://www.6212hp.nl/SES-archief/krant/overz_div23.htm\#top

Dagblad De Limburger (2008) Kiezersangst Beheerst ENCI-discussie. Retrieved 24-04-2016, from http://www.6212hp.nl/SES-archief/krant/overz_div26.htm\#top 
Dagblad Trouw (2008) Mergelgroeve Dicht na Burgerinitiatief. Retrieved 24-04-2016, from http://www.6212 hp.nl/SES-archief/krant/overz_div25.htm\#top

de Trompetter (2007) Iniatiatief Tegen Vergunning ENCI. Retrieved 24-04-2016, from http://www.6212hp. nl/SES-archief/krant/overz_div23.htm\#top

Dewald U, Achternbosch M (2015) Why did more sustainable cements failed so far? Disruptive innovations and their barriers in a basic industry, forthcoming in environmental innovation and societal transitions

ECOBA (2016) Who is ECOBA. Retrieved 11-04-2016, from http://www.ecoba.com/whoisecoba. $\mathrm{html}$; jsessionid=2B6C28EF7636A857394ADEDF2F68D1AA

Eikelboom R, Ruwiel E, Goumans J (2001) The building materials decree: an example of a Dutch regulation based on the potential impact of materials on the Environment. Waste Manag 21(3): 295-302

Emission Authority The Netherland (2016) NEa transfers emission allowances 2016. Retrieved from https://www.emissionsauthority.nl/topics/allocation-of-ets-allowances/news/2016/02/25/nea-transfersemission-allowances-2016

EN 197-1 (2011) Cement - part 1: composition, specifications and conformity criteria for common cements. NEN, Delft

ENCI (2004) Persbericht ENCI (18-06-2004). Retrieved 24-04-2016, from http://www.6212hp.nl/SESarchief/krant/overz_div15.htm\#top

ENCI (2014a) IJmuiden, Rotterdam - Bedrijfsprofiel 2014/2015. ENCI - HeidelbergCement Benelux. Retrieved from http://www.enci.nl/n1/enci-ijmuiden

ENCI (2014b) Maastricht - Bedrijfsprofiel 2014/2015. ENCI - HeidelbergCement Benelux. Retrieved from http://www.enci.nl/nl/enci-maastricht

Enci Stop (2001) Waarom stichting EnciStop? Retrieved 24-04-2016 from http://www.encistop.nl/

Erens F, de Man A, Janssen J (2003) Zuiveringschap Limburg en ENCI lossen slibprobleem op, H2O, 6:22-25

EURELECTRIC (2012) Commission consultation on the review of the hazardous properties Retrieved from http://www.eurelectric.org/media/27220/eurelectric_final_letter european_waste_list__hazardous_ properties_may2012_-2012-030-0495-01-e.pdf

European Commission (2000) Commission decision on the European list of waste european commission Retrieved from http://eur-lex.europa.eu/LexUriServ/LexUriServ.do?uri=CONSLEG:2000D0532 :20020101:EN:PDF

European Commission (2006) An EU strategy for biofuels. European Commission. Retrieved from http://eurlex.europa.eu/legal-content/EN/TXT/HTML/?uri=URISERV:128175\&from=EN

European Commission (2014) Commission decision determining, pursuant to directive 2003/87/EC of the European Parliament and of the Council, a list of sectors and subsectors which are deemed to be exposed to a significant risk of carbon leakage, for the period 2015 to 2019. European Commission. Retrieved from http://eur-lex.europa.eu/legal-content/EN/TXT/PDF/?uri= CELEX:32014D0746\&from $=\mathrm{EN}$

European Commission (2016) The EU emissions trading system (EU ETS) Retrieved from: http://ec.europa. eu/clima/policies/ets/index_en.htm

European Committee for Standardization (2000) Cement - part 1: composition, specifications and conformity criteria for common cements Retrieved from http://eur-lex.europa.eu/legal-content/EN/TXT/PDF/?uri= CELEX:32014D0746\&from=EN

European Parliament (2009) Directive 2009/28/EC of the European Parliament and of the Council of 23 April 2009 on the promotion of the use of energy from renewable sources. European Commission. Retrieved from http://eur-lex.europa.eu/legal-content/EN/TXT/PDF/?uri=CELEX:32009L0028\&from=EN

Feuerborn H-J (2005) Coal ash utilisation over the world and in Europe. Paper presented at the workshop on environmental and health aspects of coal ash utilization. Tel-Aviv, Israel

Garud R, Rappa MA (1994) A socio-cognitive model of technology evolution: the case of cochlear implants. Organ Sci 5(3):344-362

Global Cement (2012) Cement in Belgium and the Netherlands. Retrieved 27-03-2016, from http://www. globalcement.com/magazine/articles/663-cement-in-belgium-and-the-netherlands

Groen M (1987) Milieutechnologie - Meer dan Milieu en Technologie. Staatsuitgeverij, Den Haag

Hendriks CA, Worrell E, De Jager D, Blok K, Riemer P (1998) Emission reduction of greenhouse gases from the cement industry. Paper presented at the Proceedings of the Fourth International Conference on Greenhouse Gas Control Technologies

Het Belang van Limburg (2003) Jonge Milieu-Activisten Protesteren tegen ENCI. Retrieved 24-04-2016, from http://www.6212hp.nl/SES-archief/krant/overz_div14.htm\#top 
Het Belang van Limburg (2004) ENCI Graaft Observant af en Wil Voorraden tot 2042. Retrieved 24-04-2016, from http://www.6212hp.nl/SES-archief/krant/overz_div15.htm\#top

IEA (2013) Deployment of the CCS in the cement industry Retrieved from http://www.ieaghg. org/docs/General_Docs/Reports/2013-19.pdf

Imbabi MS, Carrigan C, McKenna S (2012) Trends and developments in green cement and concrete technology. International Journal of Sustainable Built Environment 1(2):194-216

Junginger M (2009) Biomass use in the Dutch cement industry - ENCI, Maastricht, The Netherlands. EUBionet3. Retrieved from http://dspace.library.uu.nl/bitstream/handle/1874/43939/story_1. pdf? sequence=2

Kemp R (1994) Technology and the transition to environmental sustainability. The problem of technological regime shifts. Futures 26(10):1023-1046

Kemp R, Loorbach D, Rotmans J (2007) Transition management as a model for managing processes of coevolution for sustainable development. Int J Sust Dev World (special issue on (co)-evolutionary approach to sustainable development) 14:78-91

Kemp R, Pontoglio S (2011) The innovation effects of environmental policy instruments - a typical case of the blind men and the elephant? Ecol Econ 72:28-36

Kingdon, J. W. (1984). Agendas, alternatives, and public policies, Vol 45. Boston: Little, Brown, pp 16528 36169

Kingdon JW (1995) Agenda, alternatives and public policy. Little, Brown, Boston

Klostermann JE, Tukker A, Cramer JM, van Dam A, van der Ven BL (1998) Product innovation and ecoefficiency: twenty-two industry efforts to reach the factor 4, vol 1 Springer Science \& Business Media

Limburgs Dagblad (2002a) Dat Diermeel Brandt als de Hel. Retrieved 24-04-2016, from http://www.6212hp. $\mathrm{nl} / \mathrm{SES}$-archief/krant/overz div10.htm

Limburgs Dagblad (2002b) Enci-Lobby. Retrieved 24-04-2016, from http://www.6212hp.nl/SESarchief/krant/overz div10.htm

Limburgs Dagblad (2002c) Enci Mag Toch Slib Verbranden. Retrieved 24-04-2016, from http://www.6212hp. nl/SES-archief/krant/overz div10.htm

Lindblom CE (1959) The science of 'muddling through'. Public Adm Rev 19:79-88

Lindblom CE (1979) Still muddling, not yet through. Public Adm Rev 39:517-526

Maringolo V (2009) Bioenergy for industry - biofuels in the cement industry. Paper presented at the European biomass association workshop. Brussels, Belgium

MPA Cement (2013) Novel cements: low energy, low carbon cements. MPA cement - mineral products association. Retrieved from http://cement.mineralproducts.org/documents/FS_12_Novel cements low energy_low_carbon_cements.pdf

MVO Nederland (2016) MVO Netwerk Beton. Retrieved 11-04-2016, from http://mvonederland.nl/mvonetwerk-beton

Nelson RR (1994) The co-evolution of technology, industrial structure, and supporting institutions. Ind Corp Chang 3:47-63

NRC-Handeslblad (2009) ENCI sluit groeve in 2018. Retrieved 24-04-2016, from http://www.6212hp. nl/SES-archief/krant/overz_div29.htm\#top

Paris JM, Roessler JG, Ferraro CC, DeFord HD, Townsend TG (2016) A review of waste products utilized as supplements to Portland cement in concrete. J Clean Prod 121:1-18

Polder RB (2012) Effects of slag and fly ash on reinforcement corrosion in concrete in chloride Environment research from the Netherlands. Heron 57(2012):3

Polder RB, Nijland TG, de Rooij MR (2013) Experience with the durability of blast furnace slag cement concrete with high slag content (CEM III/B) in the Netherlands since the 1920's. States Vegvesens. Retrieved from http://www.vegvesen.no/_attachment/588406/binary/940831?fast_title $=\mathrm{Nr}+270$ +Slag+cement+concrete-+the+Dutch+experience.pdf

Politico (2016) Climate targets suffer as carbon price slumps Retrieved from http://www.politico. eu/article/carbon-eu-ets-emissions-trading-system-oil-gas/

Reuters (2015) Netherlands hands out 46 million free carbon allowances to industry Retrieved from http://www.reuters.com/article/us-carbon-netherlands-idUSKBNOLU1OY20150226

Rhodes RA (1990) Policy networks a British perspective. J Theor Polit 2(3):293-317

RILEM (2007) Alkali activated materials. Retrieved 11-04-2016, from http://www.rilem.org/gene/main. php?base $=8750 \& g p \_i d=232$

Sabatier P (1993) "Policy Change over a Decade or More." In: Sabatier P and Jenkins-Smith H (eds) Policy change and learning: an advocacy coalition approach. Westview Press, Boulder, CO, p 13-39

Sabatier PA (1988) An advocacy coalition framework of policy change and the role of policy-oriented learning therein. Policy Sci 21(2-3):129-168 
Sabatier PA, Jenkins-Smith H (1993) Policy change and learning: an advocacy coalition framework. Westview, Boulder

Sandbag (2016) Cement - the final carbon fatcat. Source: https://sandbag.org.uk/reports/final-carbon-fatcat/

Schneider M, Romer M, Tschudin M, Bolio H (2011) Sustainable cement production - present and future. Cem Concr Res 41(7):642-650

Sun H, Jain R, Nguyen K et al (2010) Clean Techn Environ Policy 12:503. doi:10.1007/s10098-009-0258-8

TNO (2014) Slag cement concrete-the Dutch experience. Source: http://www.vegvesen.no/_attachment/588406 /binary/940831?fast_title=Nr+270+Slag+cement+concrete-+the+Dutch+experience.pdf

UNEP (2016) Eco-efficient cements, potential, economically viable solutions for a low- $\mathrm{CO}_{2}$, cement-based materials industry. United Nations Environment Programme, Paris

Van den Belt H, Rip A (1987) The Nelson-winter-Dosi model and synthetic dye chemistry. In: Bijker WE, Hughes TP, Pinch T (eds) The social construction of technological systems: new directions in the sociology and history of technology. MIT Press, Cambridge, pp 135-158

Van der Vooren A, Reudink M, Hanemaaijer A (2015) Eco-innovatie in gevestigde productieketens. Een analyse van de beton- en de glastuinbouwketen, PBL Planbureau voor de Leefomgeving

Van Eijk RJ, Brouwers H (2002) Stimulating the use of secondary materials in the construction industry: the role of certification. International Journal for Construction Marketing (IJCM) 3(2):43-50

Van Eijk RJ, te Winkel H, Stam AF (2011) Environmental and health aspects of coal and biomass co-combustion ashes. Paper presented at the proceedings of the world of coal ash (WOCA) conference, Denver, CO, USA

Vliegasunie (2016) About Vliegasunie BV. Retrieved 11-04-2016, from http://www.vliegasunie. nl/engels/about.php

Walsh L (2016) ETS not decarbonising cement industry, 17 March 2016. Source: http://www. endswasteandbioenergy.com/article/1387908/ets-not-decarbonising-cement-industry

WBCSD (2002) The cement sustainability initiative: our agenda for action Retrieved from http://www. wbcsdcement.org/index.php/en/about-csi/agenda-for-action

WBCSD (2015) Low carbon technology partnerships initiative - cement Retrieved from http://lctpi. wbcsdservers.org/wp-content/uploads/2015/12/LCTPi-Cement-Report.pdf

WBCSD \& IEA (2009) Cement technology roadmap 2009: carbon emissions reductions up to 2050 Retrieved from https://www.iea.org/publications/freepublications/publication/Cement.pdf

Weiss, C. H. (1983). Ideology, interests, and information. In ethics, the social sciences, and policy analysis (pp. 213-245). Springer, US

Woldekidan MF (2006) Performance study of C-fix in porous asphalt concrete using a 2D finite element model. M.Sc. Thesis - Delft University of Technology. Retrieved from http://www.road.tudelft. nl/fileadmin/Faculteit/CiTG/Over_de_faculteit/Afdelingen/Afdeling_Bouw/__Secties/Sectie_Weg_en_ Railbouwkunde/__Leerstoelen/Leerstoel_Wegbouwkunde/__Onderwijs/__MSc_Afstudeerprojecten/doc/Woldekidan___Final_Thesis_report.pdf

Woolley G, Goumans J, Wainwright P (2000) Waste materials in construction: science and engineering of recycling for environmental protection, vol 1 . Elsevier

Zundel S, Erdmann G, Kemp R, Nill J, Sartorius C (2005) Conclusions-a time-strategic ecological innovation policy. In: Sartorius C \& Zundel S (eds) Time strategies, innovation, and environmental policy. Edward Elgar, Cheltenham, p 322-348 